\begin{tabular}{|l|l|l||}
\hline \multicolumn{2}{|c|}{ PublisherInfo } \\
\hline \hline PublisherName & $:$ & BioMed Central \\
\hline \hline PublisherLocation & $:$ & London \\
\hline \hline PublisherImprintName & $:$ & BioMed Central \\
\hline \hline
\end{tabular}

\title{
Restriction enzyme scissor cut
}

\begin{tabular}{|l|l|l||}
\hline \multicolumn{2}{|c|}{ ArticleInfo } \\
\hline \hline ArticleID & $:$ & 3983 \\
\hline \hline ArticleDOI & $:$ & $10.1186 /$ gb-spotlight-20010219-02 \\
\hline \hline ArticleCitationID & $:$ & spotlight-20010219-02 \\
\hline \hline ArticleSequenceNumber & $:$ & 54 \\
\hline \hline ArticleCategory & $:$ & Research news \\
\hline \hline ArticleFirstPage & $:$ & 1 \\
\hline \hline ArticleLastPage & $:$ & 2 \\
\hline \hline & & RegistrationDate : 2001-02-19 \\
ArticleHistory & $:$ & OnlineDate \\
\hline \hline ArticleCopyright & $:$ & BioMed Central Ltd2001 \\
\hline \hline ArticleGrants & $:$ & \\
\hline \hline ArticleContext & $:$ & 130592211 \\
\hline \hline
\end{tabular}




\section{Jonathan B Weitzman}

Email: jonathanweitzman@hotmail.com

BglII is a type-II restriction endonuclease (RE) that recognizes and cleaves the DNA sequence AGACTC. The crystal structure of $B g / I I$ bound to DNA resembles other REs, with a major $\alpha / \beta$ core domain containing a central $\beta$ sheet flanked by $\alpha$ helices. In the February Nature Structural Biology, Lukacs et al. describe the structure of the free BglII enzyme, which provides an understanding of how DNA enters the binding cleft for hydrolysis (Nat Struct Biol 2001, 8:126-130). It seems, from the freeenzyme structure, that an unusual scissor-like motion allows the entry of DNA. The individual monomers swing out by as much as $50^{\circ}$, like scissor blades, producing significant effects on the tertiary and quaternary structure. The free- $B g I I I$ structure offers a new model for understanding protein-DNA recognition events.

\section{References}

1. Cloning and characterization of the $\mathrm{Bg} / \mathrm{II}$ restriction-modification system reveals a possible evolutionary footprint.

2. Understanding the immutability of restriction enzymes: crystal structure of BglII and its DNA substrate at $1.5 \mathrm{~A}$ resolution.

3. Nature Structural Biology, [http://structbio.nature.com] 